\title{
Erythrocyte Distribution Width Measurement
}

National Cancer Institute

\section{Source}

National Cancer Institute. Erythrocyte Distribution Width Measurement. NCI Thesaurus.

Code C64800.

An index of the variation in the size of the red cells and can be used to detect subtle degress of anisocytosis. It is computed directly from the RBC histogram and is calculated as a standard statictical value, the coefficient of variation of the red cell volume ditribution (ratio of standard deviation and mean copuscular volume). 